\title{
Marta Walkusz
}

Biblioteka Główna Akademii Muzycznej

im. Stanisława Moniuszki w Gdańsku

e-mail:m.walkusz@amuz.gda.pl

\section{Charakterystyka muzycznych varsavianów wydanych w latach 1875-1918 przechowywanych w Bibliotece Głównej Akademii Muzycznej im. Stanisława Moniuszki w Gdańsku}

DOI: http://dx.doi.org/10.18778/0860-7435.27.01

\begin{abstract}
Abstrakt: Warszawskie edytorstwo muzyczne począwszy od ostatniej ćwierci XIX w., stanowi nie ruszany dotąd w badaniach bibliologicznych materiał. W oparciu o metodologię zastosowaną w publikacji Warszawskie edytorstwo muzyczne w latach 1772-1865 autorstwa Wojciecha Tomaszewskiego (1992b), autorka artykułu przeprowadziła podobną charakterystykę druków muzycznych wydanych z warszawskim adresem wydawniczym w latach 1875-1918, przechowywanych w Bibliotece Głównej Akademii Muzycznej im. Stanisława Moniuszki w Gdańsku [dalej: BG AMuz]. Zwróciła przy tym uwagę na temat również dotąd nie badany - występujące w warszawskich muzykaliach zachowanych w BG AMuz relacje kontrahenckie między wydawcami a drukarniami, i wyodrębniła stricte muzyczne zakłady drukarskie.
\end{abstract}

Słowa kluczowe: warszawskie druki muzyczne; warszawscy wydawcy muzyczni; księgozbiory; typografia muzyczna; Biblioteka Główna Akademii Muzycznej im. Stanisława Moniuszki w Gdańsku 


\section{Wstęp}

- Niniejszy artykul jest jednym z pierwszych intencjonalnych spojrzeń na muzyczną wytwórczość wydawniczą warszawskich wydawców w latach 1875-1918. Muzyczne edytorstwo okresu popowstaniowego było mocno wpisane w ogólną historię warszawskiego księgarstwa i drukarstwa; dzięki temu, zarówno pod względem wykorzystywanych technik poligraficznych, układu handlowo-przemysłowego, jak i ogólnego poziomu estetycznego wydawnictw nie odstawało ono od innych form wydawniczych. Mimo to w opracowaniach historycznych nie jest omawiane osobno, lecz wciąż stanowi temat przywoływany od strony innego zadanego problemu badawczego. $\mathrm{Mu}-$ zyczny repertuar wydawniczy traktowany jest wówczas wyłącznie w sposób ogólny, lokujący muzykalia w kategorii sztuki i zespalający je z teatraliami oraz publikacjami z zakresu estetyki (Arct \& Pawłowska, 1961, s. 320-384). Jednym z priorytetów piszącej stała się więc charakterystyka bibliologiczna oraz treściowa (muzyczna) tego materiału. Według autorki najlepszym wzorcem metodologicznym w tej kwestii jest publikacja Warszawskie edytorstwo muฐyczne w latach 1772-1865 Wojciecha Tomaszewskiego (1992b), więc na jej podstawie przeprowadziła ona badania $\mathrm{z}$ autopsji, poddając analizie muzyczne varsaviana wydane w latach 1875-1918, przechowywane w Bibliotece Głównej Akademii Muzycznej im. Stanisława Moniuszki w Gdańsku [dalej BG AMuz]. Charakterystyka tego księgozbioru została przeprowadzona dwojako: pod względem muzycznym oraz bibliologicznym. Analiza muzyczna uwzględniła liczbę oraz narodowość kompozytorów, zastosowane formy muzyczne i obsady wykonawcze, a także serie wydawnicze z podziałem na rozmaite kryteria, zarówno formalne, jak i pod względem obsady i przeznaczenia wykonawczego. Analiza bibliologiczna objęła przede wszystkim charakterystykę typograficzna zbioru, w tym zarys problematyki zastosowanych w muzykaliach okresu 1875-1918 metod typograficznych w odniesieniu do zdobyczy technologicznych w kraju i w Europie.

W ramach przyjętego materiału, istotnym aspektem badawczym jest zwrócenie uwagi na występujące w warszawskich muzykaliach zachowanych w BG AMuz relacje kontrahenckie między wydawcami a drukarniami - temat ten dotąd nie poruszany, którego celem jest uwydatnienie stricte muzycznej działalności warszawskich drukarni. 


\section{Warszawskie muzykalia przechowywane w Bibliotece Głównej Akademii Muzycznej im. Stanisława Moniuszki w Gdańsku - typo- logia muzyczna}

Druki muzyczne wydane $z$ warszawskim adresem wydawniczym stanowia kolekcję w liczbie 371 tytułów. W skład księgozbioru wchodzą instrumentalne i wokalno-instrumentalne utwory muzyczne, zarówno pojedyncze dary, jak i części kilku kolekcji przekazanych przez dawnych wykładowców Akademii Muzycznej w Gdańsku, ich rodziny i studentów oraz czytelników Biblioteki ${ }^{1}$.

Pod względem występowania kompozytorów dzieł muzycznych, kolekcja jest bardzo zróżnicowana. Przeważają twórcy polscy, następnie włoscy, niemieccy, francuscy. Kilku kompozytorów pochodzi z Austrii, Stanów Zjednoczonych, Szwecji i Węgier; jednostkowo z Argentyny, Białorusi, Belgii, Czech, Danii, Rosji i Norwegii. Najwięcej dzieł zostało skomponowanych przez Fryderyka Chopina (1810-1849) - 71 tytułów, następnie Stanisława Moniuszkę (1819-1872) - 54, Piotra Maszyńskiego (1855-1934) - 15, Zygmunta Noskowskiego (1846-1909) - 7, Mieczysława Karłowicza (1876-1909) - 5, Ignacego Kossobudzkiego (1873-1936) - 5, Karola Szymanowskiego (1882-1937) - 5 i Aleksandra Zarzyckiego (1834-1895) - 5. Inni kompozytorzy skomponowali mniej niż po cztery tytuły uwzględnione w spisie. Spośród kompozytorów zagranicznych najwięcej kompozycji napisał Norweg, Edvard Hagerup Grieg (1843-1907) - 10 utworów, następnie kompozytorzy włoscy tacy jak Pietro Mascagni (1863-1945) - 6, Giacomo Puccini (1858-1924) - 5, Giu-

\footnotetext{
${ }^{1}$ Najcenniejsze kolekcje varsavianón trafiły do BG AMuz w ramach spuścizn śpiewaków: Kazimierza Czekotowskiego (1901-1972), Marii Bojar-Przemienieckiej (1897-1982), Haliny Mickiewiczówny (1923-2001), Romana Heisinga (1902-1989) oraz pianisty Zbigniewa Śliwińskiego (1934-2003). Spuścizny K. Czekotowskiego oraz M. Bojar-Przemienieckiej zostały przekazane w 1999 r. przez prof. Piotra Kusiewicza, wokalistę i pedagoga Akademii Muzycznej w Gdańsku. Dar ten liczy w sumie 538 egzemplarzy druków muzycznych; varsaviana wpisano do protokołów wpływu: N 27/99-N 32/99 oraz N 35/99 i N 38/99. Księgozbiór H. Mickiewiczówny przekazała w 2002 i 2004 r. jej wnuczka, Justyna Trapkowska. Część spuścizny zawierająca ikonografię, pamiątki rodzinne oraz dokumentację, przechowywana jest w charakterze depozytu, stąd jego zawartość nie została dotychczas uporządkowana. Pozostała część daru, włączona w stały zasób Biblioteki, zawiera nuty: 475 druków (interesujące autorkę varsaviana wpisano w protokołach wpływu: N-47/2002 i N 48/2002, N 5/2004-N 9/2004, N 11/2004, N 19/2004 i N 22/2004) oraz rękopisy (wciąż czekające na włączenie do zbiorów i skatalogowanie). W 606 egzemplarzach nut podarowanych przez Z. Śliwińskiego znaleziono 65 utworów F. Chopina w serii Oeuvres de Piano, Édition de Jean Klecaynnski; Revue et corrigée d'après les premières autorités pédagogiques et artistiques par Rodolphe Strobl (wpisane w protokołach wpływu: N 47/2004, N 58/2004 oraz N 62/2004—N-64/2004). Spośród nut ze spuścizny R. Heisinga, darowanych przez niego samego (protokół N 49/78) oraz córkę śpiewaka - Amelię Poszowską (protokoły: N 7/90 i N 8/90), tylko siedem druków spełnia badane przez autorkę kryteria.
} 
seppe Verdi (1813-1901) - 5 oraz niemieccy: Ludwig van Beethoven (1770-1827) - 4 tytuły, Felix Mendelssohn-Bartholdy (1809-1847) - 4 i Moritz Moszkowski (1854-1925) ${ }^{2}-4$. Sa to przede wszystkim kompozytorzy żyjący na przełomie XIX i XX wieku, tylko kilkunastu urodziło się jeszcze w wieku XVIII, trzech w wieku XVII.

Wśród wokalno-instrumentalnych form muzycznych dominuje pieśń na głos i fortepian. Na drugim miejscu występują aranżacje arii z oper w opracowaniu partii orkiestrowej na fortepian. Praktyka sporządzania wyciagów fortepianowych fragmentów oper była wyrazem popularności samej opery w Warszawie i przynosiła wielostronne korzyści; jej niewyczerpany materiał stanowił źródło utrzymania dla kompozytorów, dla twórców opracowań fortepianowych ${ }^{3}$ oraz, w przypadku dzieł obcojęzycznych, dla autorów polskich przekładów ${ }^{4}$. Dla wydawców nut oraz dla wykonawców, fortepianowe transkrypcje oper stanowiły istotne wsparcie ich działalności. Ciekawa praktyka była również aranżacja utworów fortepianowych na głos i fortepian. W zbiorze obecne sa transkrypcje dzieł F. Chopina, wydawane osobno oraz w ramach serii „Utwory Chopina ułożone do śpiewu” Gebethnera i Wolffa (Chopin, [1905-1910]).

Zdecydowaną mniejszość stanowią duety wokalne $z$ towarzyszeniem fortepianu, są to zarówno utwory skomponowane oryginalnie na dwa głosy i fortepian, jak i wyciagi fortepianowe duetów pochodzących z oper. Zanotowano tylko jeden tercet: na sopran, tenor, baryton i fortepian, w układzie oryginalnym (Dargomyżski, [po 1911]). W kolekcji obecne są również wyciagi fortepianowe całych oper: Halki oraz Verbum nobile S. Moniuszki.

W ramach muzyki instrumentalnej przeważaja kompozycje fortepianowe (na dwie lub, w mniejszości, na cztery ręce). Wśród nich należy wyróżnić utwory pisane oryginalnie na fortepian oraz aranżacje. Większość z nich wydana jest $\mathrm{w}$ ramach serii dydaktycznych lub z określonym przeznaczeniem wykonawczym, o których będzie mowa później.

\footnotetext{
${ }^{2}$ Moritz (Maurycy) Moszkowski urodził się we Wrocławiu, więc mimo tego, że rodzina posiadała polskie korzenie, uznawany jest za kompozytora niemieckiego. Często występował w Warszawie jako pianista, prezentując przede wszystkim własne utwory, oraz jako dyrygent (Poniatowska, 2000, s. 384-385).

${ }^{3}$ Wśród nich pojawiali się tacy wybitni kompozytorzy warszawscy jak P. Maszyński, Henryk Waghalter (1869-1958) czy Gustaw Roguski (1839-1921).

4 Ze sporządzonego spisu nut należy wyodrębnić takich autorów polskiego tłumaczenia jak: Jan Chęciński (1826-1874), P. Maszyński, Stella Milner (daty życia nieznane), Maksymilian Radziszewski (1828-?), Wincenty Rapacki (1865-1943), Feliks Schober (1846-1879), Władysław Sterling (1876- około 1943), Zofia Vieweger (1860- przed 1945), Jan Woźnicki (1874-1926), Stanisław Zadarnowski, pseud. Ratold (1893-1926) i Ignacy Ziółkowski (daty życia nieznane). Teksty na własne potrzeby tłumaczył również m.in. śpiewak Tadeusz Leliwa (1875-1929), wydawcy poświęcali mu nawet serie kolekcjonerskie (zob. Bettinelli, [1911]).
} 
Dzieła na inne instrumenty stanowia jednostkowe przypadki; wśród nich należy wyróżnić jedynie Danse hongroise Johannesa Brahmsa w transkrypcji na skrzypce i fortepian Romualda Austa ([19?]), trio na skrzypce, wiolonczelę i fortepian Mazourka F. Chopina w transkrypcji Antoniego Cinka ([1909-1913]), Szkołe na organy, cz. 1 Henryka Makowskiego i Mieczysława Surzyńskiego ([po 1895]) oraz Méthode pour Hautbois Théorique et Pratique Zygmunta Singera ([około 1912]).

Kolejną wyodrębnioną kategorię stanowi muzyka chóralna. Są to przede wszystkim śpiewniki zawierające pieśni na czterogłosowy chór mieszany lub męski, zebrane i opracowane lub skomponowane przez P. Maszyńskiego i Tadeusza Joteykę (1872-1932), a także tzw. „hasła” muzyczne napisane dla chórów (także dla tych spoza Warszawy) przez różnych kompozytorów (Hasta „Lutni”..., [1898]). Odmienną obsadę posiadają Pieśni weselne Eugeniusza Pankiewicza (1857-1898), skomponowane na duet wokalny lub dwugłosowy chór żeński z towarzyszeniem fortepianu w układzie na cztery ręce (1912-1915).

Na szczególną uwagę zasługuje Milda, kantata mitologiczna litewska S. Moniuszki ([1909]), jedyny w całym omawianym zbiorze przykład pełnej partytury dzieła wokalno-instrumentalnego, będący litografowanym faksymile rękopisu. Warto podkreślić, iż jest to pierwsze wydanie tej kantaty, które opublikowane było równocześnie w postaci wyciagu jak i partytury wraz z głosami orkiestrowymi (Mazur, 1970, s. 160, 224).

\section{Serie wydawnicze}

L Pośród serii nutowych wydawanych w latach 1875-1918 możemy wyróżnić następujący podział: ze względu na obsadę wykonawczą, na fortepianowe transkrypcje popularnych fragmentów dzieł scenicznych, ze względu na wybór kompozytorów (w tym podział na kompozytorów polskich i obcych), na utwory ze słowami danego autora, ze względu na rodzaj, formę, czy gatunek muzyczny, na dzieła z danym przeznaczeniem dydaktycznym, domowym, salonowym i rozrywkowym, z określeniem stopnia trudności wykonania (bez konotacji pedagogicznych) lub wieku wykonawców, a także kategorię: muzyka religijna. W badanym zbiorze gdańskim odnaleziono wiele przykładów serii, w obrębie których wydawano dzieła wokalno-instrumentalne. Zostały one wymienione począwszy od wydawców, u których zanotowano największą liczbę serii, kończąc na jednostkowych reprezentacjach. Podano również liczbę tytułów występujących w każdej serii wraz z ustalonymi datami wydania dzieł. Szczególne przypadki datacji, wymagające wyjaśnienia, zostały omówione w odpowiednich przypisach. 
I tak, u Gebethnera i Wolffa znaleziono 16 serii: Cacilia. Zbiór Śpiewów Religijnych ₹. Towaryyszeniem Organu lub Fortepianu (1 tytuł datowany [po 1908], 3 tytuły wydane [po 1913] $]^{5}$ ), Chabry. Zbiór Śpiewów Polskich Kompozytorów na Jeden Gtos z Towarzyszeniem Fortepianu (3 tytuły: datacja pierwszego tytułu ustalona wg BN, por. Kossobudzki, [1908-1912], 2 tytuły: [1912-1915]), Co Śpiewa Warszawa. Wybór Piesni, Piosnek i Kupletów Śpiewanych na Koncertach $i$ w Teatrach (2 tytuły, datowane [po 1910] i [1908-1914]), Cudne D źwiekei. Wybór Śpiewów Polskich i Obcych Kompozytorów na Jeden Glos z. Towarzyszeniem Fortepianu (data wydania jednego tytułu według pozwolenia cenzury: 1904 oraz drugiego: [przed 1910]), Hosanna. Zbiór Śpiewów Religijnych z. Towarzyszeniem Organu lub Fortepianu (1 tytuł: Münchheimer, [po 1908]), Lira. Zbiór Śpiewów Polskich i Obcych Kompozytorów na Jeden i Dwa Glosy z. Towarzyszeniem Fortepianu $i$ Innych Instrumentów (33 tytuły wydane w różnych latach między 1893 r. a 1915 r.), Opera w Salonie. Wyjatki z Oper Polskich, W toskich, Francuskich $i$ Niemieckich na Rozmaite Gtosy, oraz Duety z. Towarzyszeniem Fortepianu (27 tytułów wydanych pomiędzy 1888 r. a 1918 r.), Pieśń Ludowa Góralska (1 tytuł: Starczewski, 1916), Śpiewy Polskie z. Towarzyszeniem Fortepianu (w ramach serii: Catery Ulubione Pieśni Śpiewane przez. Alicye Barbi) (1 tytu1: Grieg, [po 1912?]), Utwory Chopina Utożone do Śpiewu (2 tytuly, pierwszy datowany na [1905-1910], drugi: 1911), Utwory Mugyczne Adama Wrońskiego, Dyrektora Orkiestry Teatru Lwowskiego i Zdrojowej Krynicy (1 tytuł: Wroński, [cenz. 1899]), Utwory Muqyczne Wilhelma Troschla. Śpiewy z. Towarzyszeniem Fortepianu (1 tytul: Troschel, [po 1910?]), Utwory Piotra Maszyńskiego (w ramach serii Do śpiewu) (2 tytuły, wydane w 1899 r. i 1910 r.), Z Repertuaru Tadeusza Leliwy (1 tytuł datowany [po 1907], 2 tytuły wydane w 1911 r.), Wybór Piosnek Polskich Utworu Stanisława Moniuszki (2 tytuły, pierwszy wydany $\mathrm{z}$ data pozwolenia cenzury 1895, drugi nawet z datą dzienną pozwolenia cenzury, zob. Moniuszko, cenz. 11.06.1901), Zbiór Ulubionych Śpiewów Ułożonych na Mezzo-Sopran z. Utatwionym Towarzyszeniem Fortepianu przez. Wilhelma Troschel. Artyste Opery (Verdi, [około 1910] $)^{6}$ (Fot. 1)

\footnotetext{
${ }^{5} \mathrm{~W}$ wielu przypadkach datacja była ustalona wyłącznie na podstawie katalogów danego wydawcy i podana w nawiasie kwadratowym, np. Wieniawski, [po 1913], wydany w serii „Cæcilia” z numerem 83. We wrześniu 1913 r. w ramach tej serii wydano numery: 75, 76, i 77. Chronologicznie więc numer 83 powinien być wydany później (choć nie jest to reguła). Zob. Przeglad Bibliograficzny Ksiegarni Gebethnera $i$ Wolffa w Warszawie, wrzesień 1913 nr 9, s. 227. Pobrane 17 października 2018, z: http://bc.wbp.lublin.pl/dlibra/plain-content?id=14096. ${ }^{6}$ Seria Zbiór Ulubionych Śpiewów (...) W. Troschla obecna jest również w drukach muzycznych wydanych nakładem G. Sennewalda, zarówno wcześniejszych, z lat 60. XIX wieku, (np. Bellini, [około 1865]), jak i późniejszych, datowanych po 1880 r. (np. Troschel, [około 1880]).
} 
Charakterystyka muzycznych varsavianów...

Fot. 1. Przykład serii Zbiór Ulubionych Śpiewów Utożonych na Mezzo-Sopran z Ułatwionym Towarayszeniem Fortepianu przez. Wilhelma Troschel. Artyste Opery

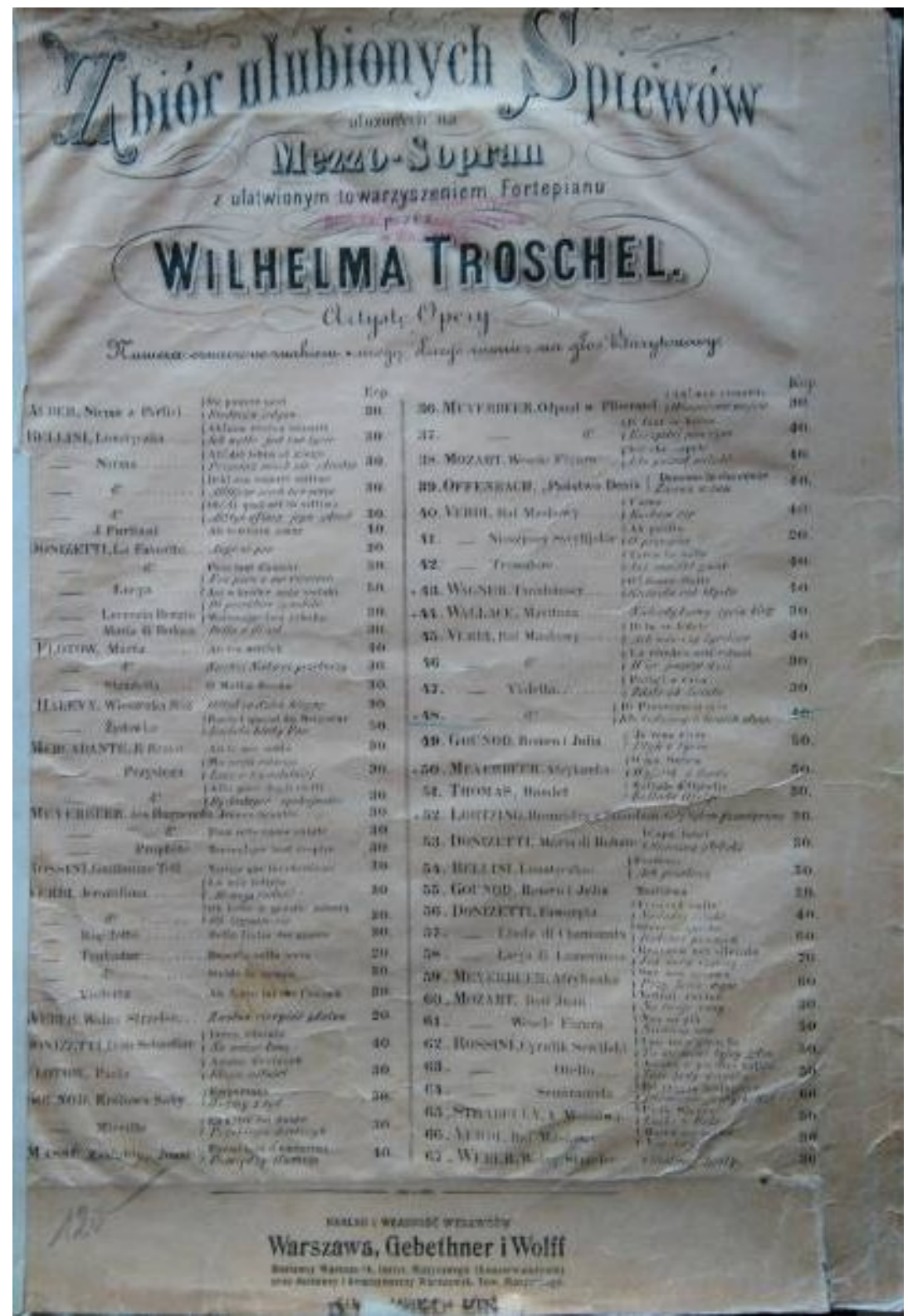

Źródło: BG AMuz: nr inw. N 47562; sygn. 78(0.068) Verdi G - Travi 2/Ger; fot. Marta Walkusz 
U Ferdynanda Hösicka odnotowano 7 serii wokalno-instrumentalnych: Chwała na Wysokości. Zbiór Kompozycji Kościelnych (1 tytul: Schubert, [około 1890]). Kolejna seria, Nuty do Śpiewu. Zbiór Najulubieńszych Śpiewów Polskich i Obcych z Towarzyszeniem Fortepianu, dzieli się na podserie. Pierwsza z nich: Repertuar Pani Artôt, Adel. i Carol. Patti, Cottonie'go, Faure'a, zapis zawsze z zachowaniem skrótów imion wokalistek (Denza, [19?]b) (Fot. 2).

Fot. 2. Przykład nazwy serii Repertuar Pani Artôt...

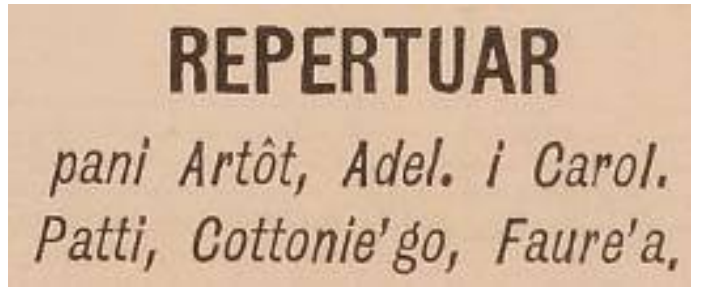

Źródło: BG AMuz: nr inw. N 4160; sygn.: 78(0.068) Denza L - Gdyby ; PBC.

Pobrane 16 października 2018, z: http://pbc.gda.pl/dlibra/docmetadata?id=14939

Druga odnaleziona podseria to Śpiewy Różnych Kompozytoróm Polskich i Obcych (Żeleński, cenz. 1900).

W dalszej kolejności odnotowano serie: Koncert w Salonie. Wybór Duecików Salonowych na Dwa Glosy Żenskie lub Mieszane (2 tytuły; ich daty wydania sa niekompletne (zob. Gabussi, [19? $\left.{ }^{7}\right]$ oraz Mendelssohn-Bartholdy, [189? $\left.{ }^{8}\right]$ ), Reszke Album. Zbiór Najulubiensaych Śpiewów Polskich i Obcych z. Towarzyszeniem Fortepianu (6 tytułów wydanych kolejno: [1880-1890], z datą cenzury 1888 - 2 tytuły, [19?], [około 1900] i [po 1903]), Romanzero. Zbiór Romansów, Aryi $i$ Duetón (2 tytuły, pierwszy z datą druku [po 1903], drugi z data [po 1907]), Śpiewnik Salonowy. Wybór Śpiewów Polskich i Obcych na Głos Mezzosopranowy $i$ Sopranowy z. Towarzyszeniem Fortepianu (2 tytuły: pierwszy z data [około 1885], drugi z datą druku [po 1903]), Z Albumu Marcelliny Kochańskiej, B. Donadio, A. Barbi i Innych. Zbiór Najpiekniejsaych Śpiewów z. Towarayszeniem Fortepianu (2 tytuły, pierwszy z datą [około 1895]) (Fot. 3).

\footnotetext{
${ }^{7}$ Biblioteka Narodowa posiada wiele wydań tego utworu, a daty wahają się między 1880 a 1904 rokiem: Mus.III.103.322 (data wyd. wg BN: cenz. 1904); Mus.III.119.260 (data wyd. wg BN: cenz. 1898); Mus.III.105.233 (data wyd. wg BN [około 1895]); Mus.III.119.264; Mus.III.119.258 (data wyd. wg BN [około 1880].

${ }^{8}$ Data wydania jest bardzo trudna do jednoznacznej identyfikacji, a brak nut w innych repozytoriach uniemożliwia dokonanie porównań. W tej formie data została przyjęta także w PBC.
} 
Charakterystyka muzycznych varsavianów...

Fot. 3. Przykład zapisu serii $Z$ Albumu Marcelliny Kochańskiej... wraz z ilustracja (Massenet, [około 1895])

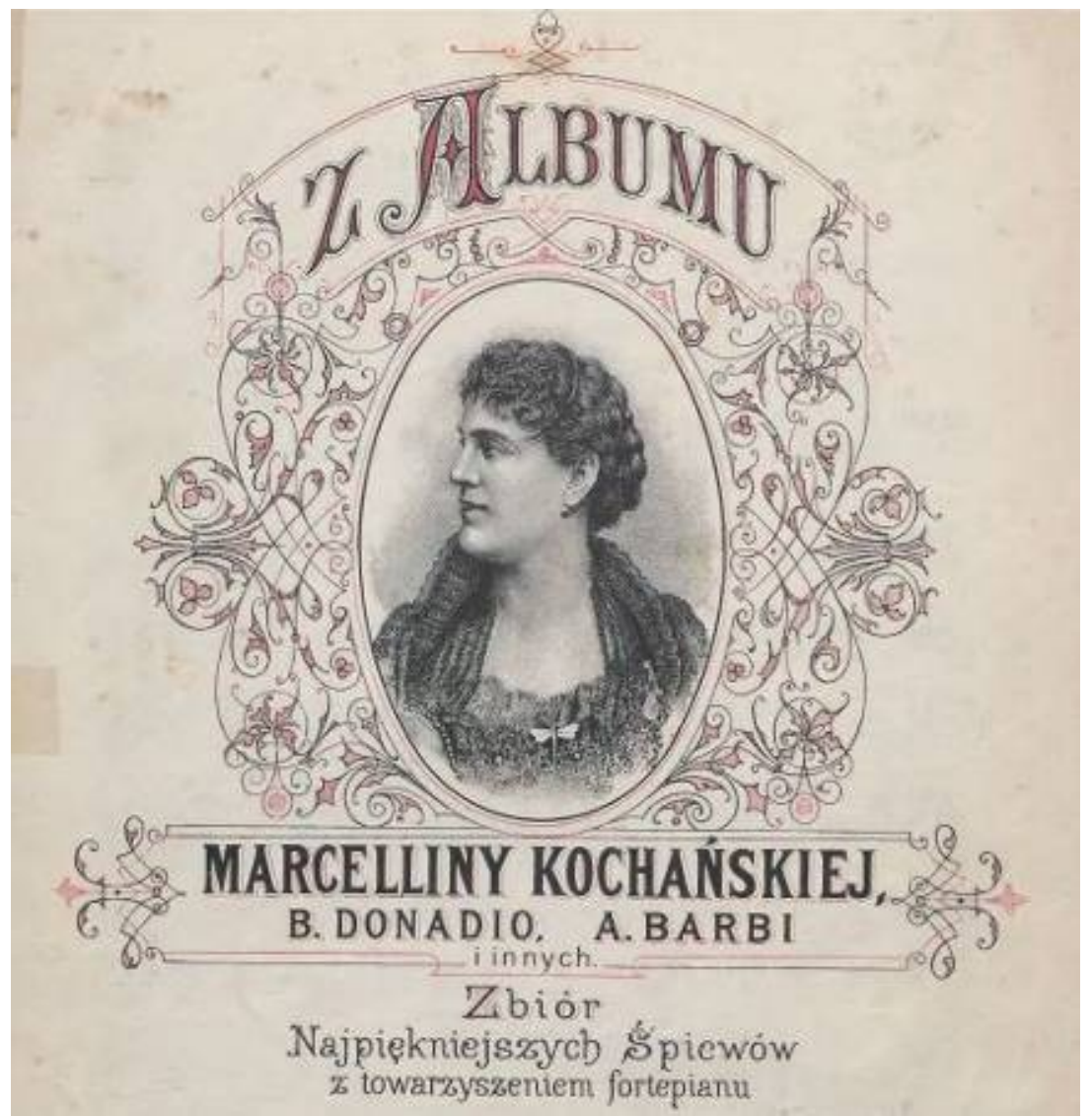

Źródło: BG AMuz: nr inw. N 44432; sygn.: 78(0.068) Masse J - Nocwh;

Pomorska Biblioteka Cyfrowa (dalej: PBC).

Pobrane 16 października 2018, z: http://pbc.gda.pl/dlibra/docmetadata?id=33167

Wśród varsavianów wydanych przez Gustawa Sennewalda, przechowywanych w BG AMuz zanotowano cztery serie. Również i w tym przypadku wszystkie zawieraja utwory wokalne: Arion. Zbiór Pieśni, Aryi i Duetón do Śpiewu z. Fortepianem Zebranych Staraniem Wilhelma Troschla, B. Artyste Opery, Nauczyciela Muayki (2 tytuły: pierwszy wydany w 1882 r. (Fot. 4), drugi: z data cenzury 1892). 
Fot. 4. Przykład serii Arion (...), (Kücken, cenz. 1882)

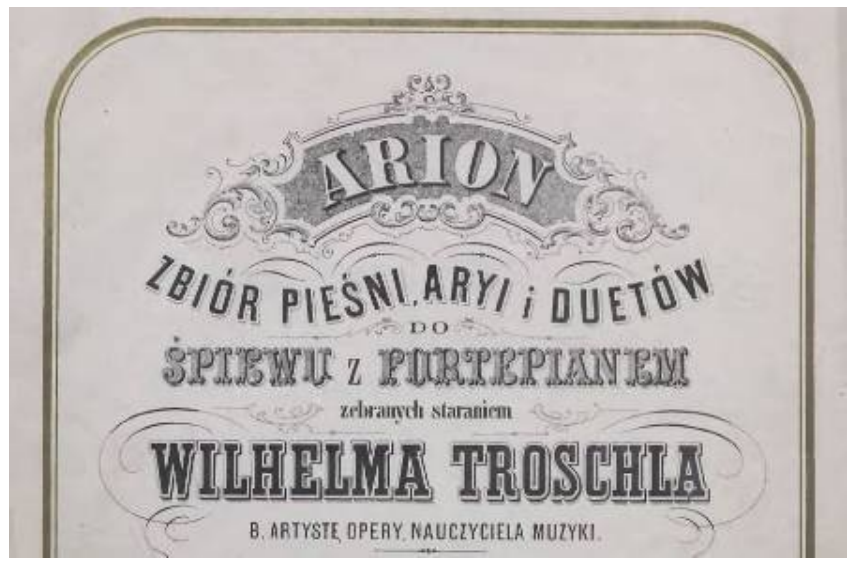

Źródło: BG AMuz: nr inw. N 44355; sygn.: 78(0.068) Kucke FW - Seren; PBC.

Pobrane 16 października 2018, z: http://pbc.gda.pl/dlibra/docmetadata?id=33826

Druga odnotowana seria G. Sennewalda to Drieła pośmiertne Wilhelma Troschla, w ramach której publikowano utwory w podseriach: Śpiewy Religijne i Śpiewy Salonowe (Troschel, cenz. 1887 [druk przed 1895]) (Fot. 5).

Fot. 5. Przykład serii Dzieła Pośmiertne Wilhelma Troschla

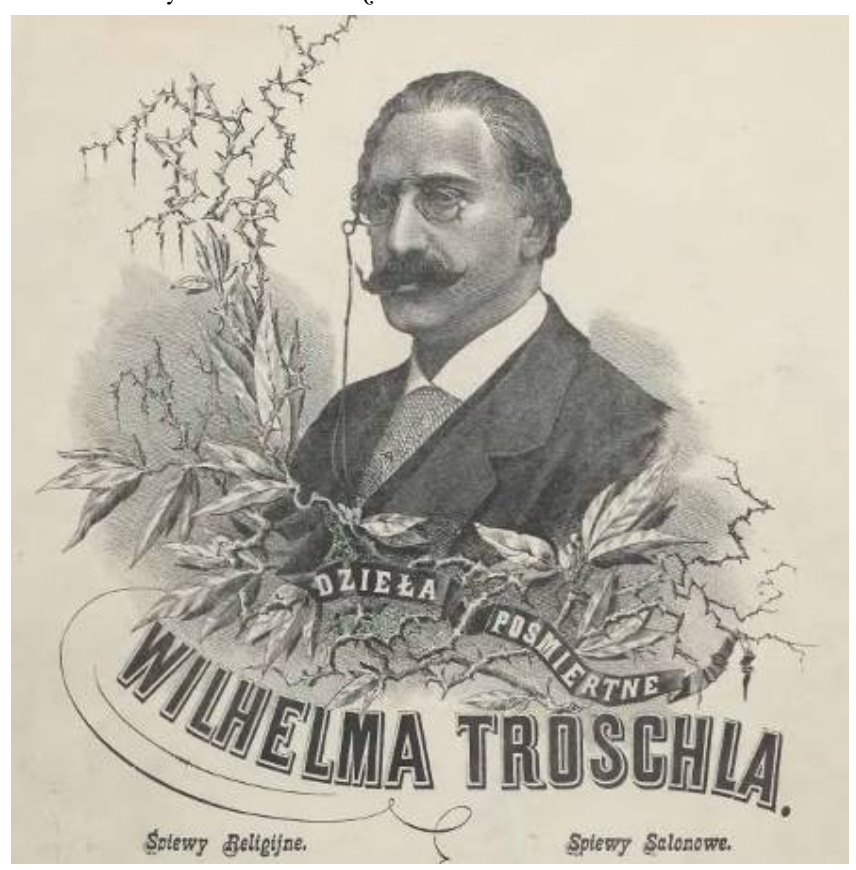

Źródło: BG AMuz: nr inw. N 44592; sygn. 78(0.068) Trosch W - Czaro; PBC.

Pobrano 16 października 2018, z: http://pbc.gda.pl/dlibra/docmetadata?id=33987 
Kolejne dwie serie Sennewalda to: Euterpe. Zbiór Ulubionych Aryi z Oper i Romansów Obcych w Przekładzie Polskim, w Przekładzie Polskim Zebranych Staraniem Jana Quattriniego (znalezione 3 tytuły, wydane kolejno: z data cenzury 1884 i 1888 oraz z data niekompletna, niepewna, por. Arditi, [189?]), a także Kłosy z. Naszej i Obcej Niwy. Zbiór Pieśni i Piosenek na Jeden i Dwa Gtosy z. Towarzyszeniem Fortepianu (5 tytułów, wydanych kolejno: cenz. 23.05.1895, [cenz. 1895] - 2 tytuly, [1905-1907] - 2 tytuly).

U Leona Idzikowskiego odnotowano dwie serie wokalne: Echa ₹. Zachodu. Wybór Najpiekniejsyych Śpiewów Obych Kompozytorów w Przektadzie Polskim z. Zachowaniem Tekstu Oryginalnego $i$ Uwaglednieniem Innych (3 tytuły z przyjętymi datami wydania: [19?], [1913-1915] i [po 1914]) oraz Pieśni Wschodu. Wybór Najpiekniejszych Śpiewón Kompozytorón Rosyjskich w Przekładzie Polskim z.Zachowaniem Tekstu Oryginalnego $i$ Uwaglednieniem Innych (Dargomyżski, [po 1911]).

U każdego z pozostałych wydawców zanotowano tylko jedną serię. U Michała Arcta: Wybór Śpiewów Salonowych na Jeden i Dwa Glosy z Towarzyszeniem Fortepianu. Obejmuje 4 tytuły wydane kolejno: z data cenzury [1893], [ok. 1900?], [około 1905] oraz z datą niemożliwą do jednoznacznej identyfikacji, stąd przyjęto dość szeroki zakres: [1890-1915] '). U Rajchmana i Frendlera: Arcydzieła Muzyki Historycznej W toskiej, Francuskiej i Niemieckiej (również 4 tytuły, wszystkie $z$ data pozwolenia cenzury 1886). U Bronisława Rudzkiego: Pod Wtoskim Niebem (1 tytuł: Denza, [19?]a), w Wydawnictwie Kruziński et Lewi: Fleurs Melodiques. Choix de Romances des Pièces Classiques et Modernes, choisies et revues par Miecislas de Horbowski, Professeur de Chant (1 tytul: Moszkowski, cenz. 1883) (Fot. 6a i 6b).

\footnotetext{
9 Zakres dat został przyjęty na podstawie kilku identycznych opisów bibliograficznych nut skatalogowanych w Bibliotece Narodowej: sygn. Mus.III.163.870 (data [około 1890]), Mus.III.150.115 (data [około 1895]) oraz Mus.III.163.871 (data [nie przed 1915]). Pomorska Biblioteka Cyfrowa przyjęła datę [po 1900], por. Heiser, [1890-1915].
} 
Fot. 6a i 6b. Przykład nazwy serii w zakładzie Kruziński et Lewi oraz stopka adresowa wydawcy (Moszkowski, cenz. 1883)
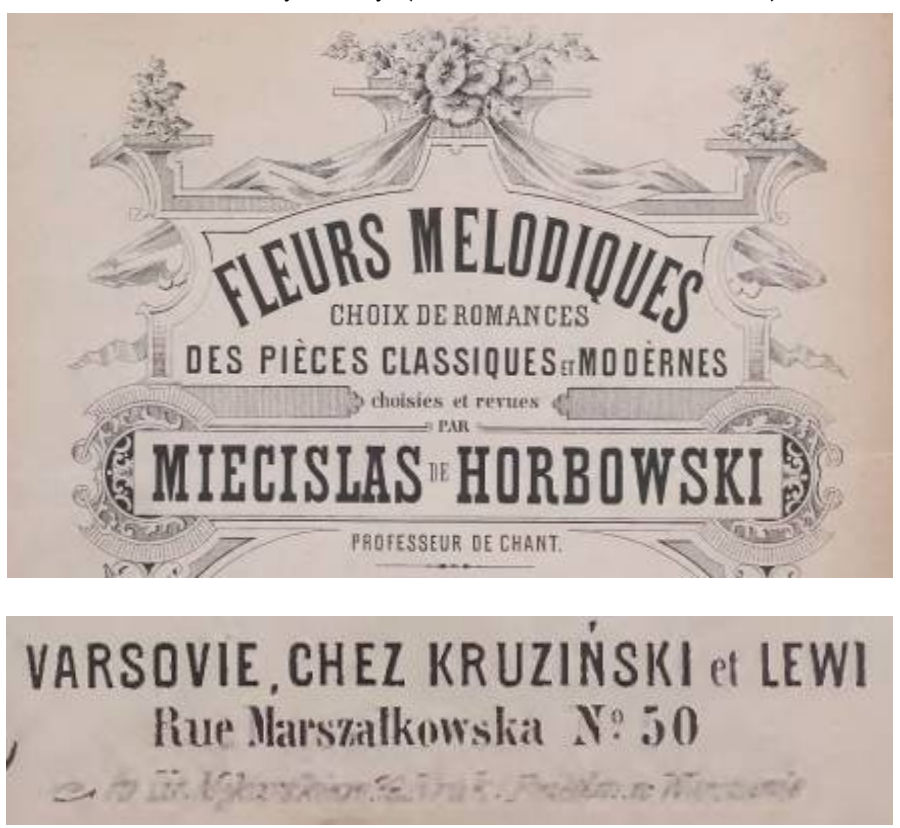

Źródło: BG AMuz: nr inw. N 44416; sygn. 78(0.068) Moszk M - Oczęt; PBC.

Pobrane 16 października 2018, z: http://pbc.gda.pl/dlibra/docmetadata?id=32548

U Stanisława Sadowskiego: Niezapominajki. Zbiór Śpiewón Swojskich i Obcych Kompozytorów Wybrat Witold Aleksandrowicz, Profesor Śpiewu, B. Artysta Opery (1 tytul, Schubert, cenz. 1899) (Fot. 7).

Fot. 7. Przykład serii Wydawnictwa S. Sadowskiego

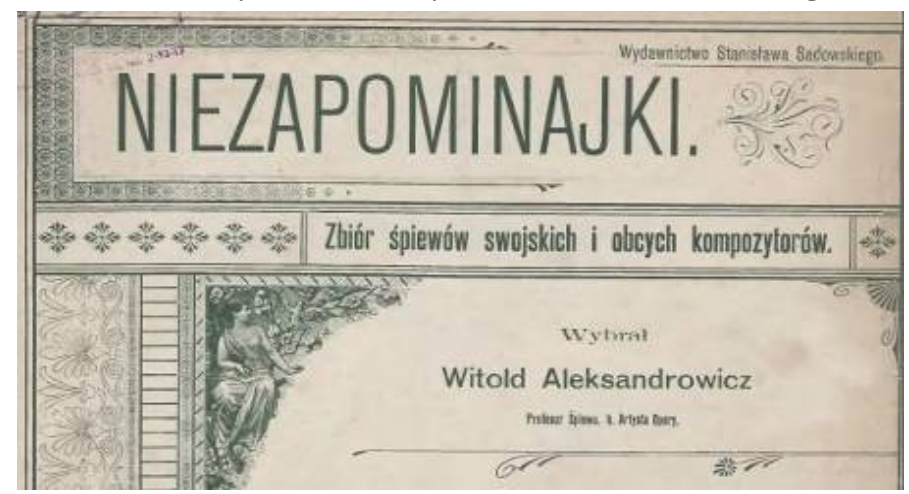

Źródło: BG AMuz: nr inw. N 47727; sygn. 78(0.068) Schub F - Letzt; PBC.

Pobrane 16 października 2018, z: http://pbc.gda.pl/dlibra/docmetadata?id=32838 
Jak już wspomniano, kompozycje fortepianowe również chętnie ujmowano w rozmaite serie. Najobszerniejsze były serie dydaktyczne, m.in. gebethnerowska seria Rudolfa Strobla (1831-1915): Choix des Compositions Classique et Modernes, w ramach której w gdańskim zasobie varsavianów zanotowano 10 tytułów, wydanych w różnych latach między cenz. 1888 a [1913-1914?], a także Le Programme des Professeurs choix de compositions de piano classées, revues et doigtées par G. Roguski, A. Różycki, A. Rutkowski, A. Sygietyński [...] avec le concours de A. Michałowski et I. Paderewski wychodząca nakładem F. Hösicka (1 tytuk: Beethoven, cenz. 1899 [druk po 1903]).

Utwory bez przeznaczenia dydaktycznego również publikowano w seriach, dzięki czemu „grupowano” dzieła np. ze względu na formę muzyczna (seria Ouvertures favorites pour piano a 2 mains, a 4 mains $\mathrm{F}$. Hösicka, obecne w BG AMuz 3 tytuły: jeden z [1890] i 2 tytuły - [przed 1910]) lub ze względu na sugerowane miejsce wykonania (seria Pianista $w$ Salonie Bronisława Rudzkiego - 1 tytuł w BG AMuz: Grieg, [około 1910]), a także po prostu ze względów kolekcjonerskich, w ramach których w BG AMuz odnotowano przykłady serii: Chrysanthemes (3 tytuly, dla których daty wydania przyjęto kolejno: [1905-1907], cenz. 1914 i [1913-1917]), Compositions des Auteurs Polonais (1 tytuł: Moniuszko, [po 1908]) i Collection de Potpourri et Ouvertures pour de Piano à deus mains (1 tytul: Suppé, (cenz. 1915) Gebethnera i Wolffa, Collection de Potpourris (1 tytul: Marks, [po 1911]) L. Idzikowskiego, Portefenille du Pianiste. Collection de Pieces Favorites pour Piano F. Hösicka (1 tytuł: Liszt, [przed 1900]) (Fot. 8.).

Fot. 8. Przykład serii dla pianistów

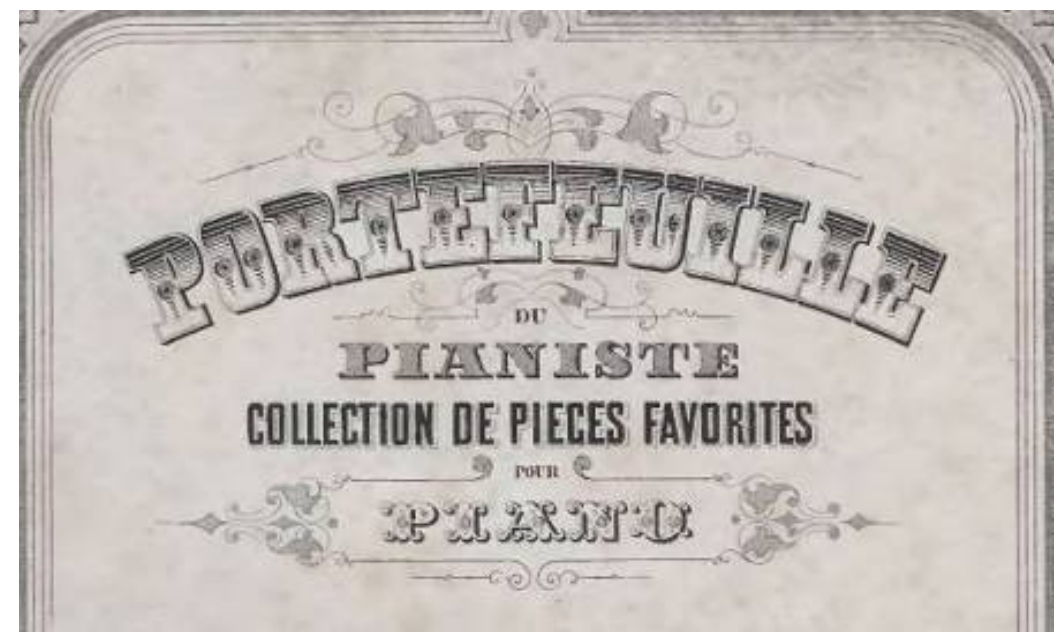

Źródło: BG AMuz: nr inw. N 33487; sygn.: 78(0.068) Liszt F - Rapso 2; PBC.

Pobrane 16 października 2018, z: http://pbc.gda.pl/dlibra/docmetadata?id=31364 
Na szczególną uwagę zasługuje obszerne, piąte wydanie dzieł F. Chopina, w ramach którego w BG AMuz przechowywanych jest 65 numerów. Wydanie to publikowano sukcesywnie w latach $1902-1915^{10} \mathrm{w}$ serii Oeuvres de Piano, Édition de Jean Kleçynski; Revue et corrigée d’après les premières autorités pédagogpédagogiques et artistiques par Rodolphe Strobl. Seria obejmuje ogółem 10 mów oznaczonych poszczególnymi numerami nadanymi w wydaniach poprzednich. Zbiór został wydany nakładem Gebethnera i Wolffa; poszczególne zeszyty mają odmienne graficznie strony tytułowe, co wynika z udziału różnych zakładów drukarskich. W ramach kolekcji przechowywanej w BG AMuz zanotowano: Drukarnię A.T. Jezierskiego, Pospieszną Litografię i Sztycharnię nut J. Mękarskiego oraz Zakłady Graficzne B. Wierzbickiego i Spółki).

Mając na uwadze powyższe rozważania, należy skonstatować, iż pod względem muzycznym, gdański zbiór varsavianów z lat 1875-1918 stanowi bardzo interesująca kolekcję: prezentuje utwory najznakomitszych i najpopularniejszych na przełomie XIX i XX wieku kompozytorów, o formach muzycznych i obsadach wykonawczych wykorzystywanych wówczas w Warszawie najczęściej. Ujmowanie dzieł muzycznych w rozmaite serie również miało swój udział w kreowaniu popytu na te wydawnictwa. Owa popularność wyrażona jest także w obecności warszawskich muzykaliów w zbiorach gdańskich muzyków działających od międzywojnia aż do początków XXI wieku, gdyż w obrębie ich bogatych spuścizn, varsaviana stanowią dość znaczny udział.

\section{Charakterystyka typograficzna zbioru}

L Pod względem typograficznym, gdańska kolekcja warszawskich muzykaliów jest zbiorem dość jednorodnym. Większość druków muzycznych to kilkustronicowe woluminy w formacie o wysokości od 20 do $34 \mathrm{~cm}$. Nie posiadają obwolut; strona tytułowa pełni również rolę okładki. Wyjątkiem są Oeuvres pour le Piano, vol. 1-3 F. Chopina. Zbiory te licza ponad 200 stron każdy i jako jedyne posiadają obwoluty; zachował się na nich ekslibris „Introligatornia i Linijowanie Papieru L. Miernickiego, Elektoralna No. 10"11 (Fot. 9.).

\footnotetext{
${ }_{10}$ Datowanie zbioru ustalono m.in. dzięki oznaczeniu cen w rublach (Chomiński \& Turło, 1990, s. 261-263).

11 Jest to właściwie wlepka reklamowa Zakładu Introligatorskiego Ludwika Miernickiego, zakwalifikowana jednak przez Bibliotekę Narodowa jako ekslibris. Wg egzemplarzy o sygn. E.5787 i E.6675 przechowywanych w BN, zmienna numeracja ulicy Elektoralnej: nr 10 i nr 45.
} 
Charakterystyka muzycznych varsavianów...

Fot. 9. Ekslibris „Introligatornia i Linijowanie Papieru L. Miernickiego, Elektoralna 10” (oryginalne wymiary: 20x17 mm) (Chopin, [1877])

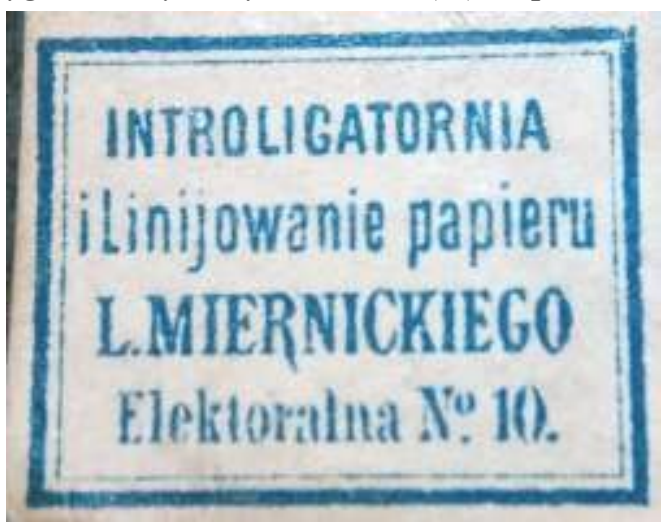

Źródło: BG AMuz: nr inw. N 31134; sygn.: 78(0.068) Chopi F - Oeuvr 1; fot. Marta Walkusz

Obwoluty te zachowały się w oryginalnej formie, noszą jednak znaczne ślady zużycia, głównie na grzbietach (Fot. 10a i 10b).

Fot. 10a. Okładki trzech tomów F. Chopin, Oeuvres pour le Piano, vol. 1-3 ([1877])

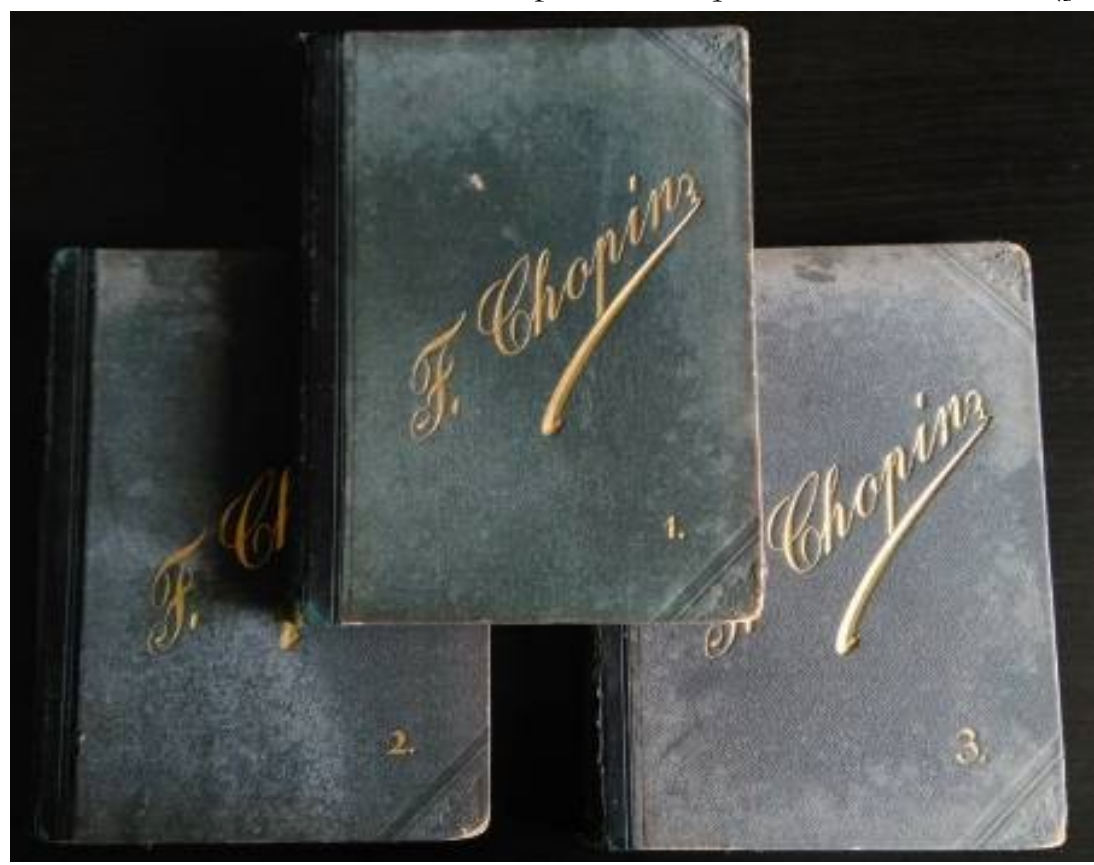

Źródło: BG AMuz: nr inw. N31134-6; sygn.: 78(0.068) Chopi F - Oeuvr 1-3; fot. Marta Walkusz 
Fot. 10b. Grzbiety trzech tomów F. Chopin, Oeuvres pour le Piano, vol. 1-3 ([1877])

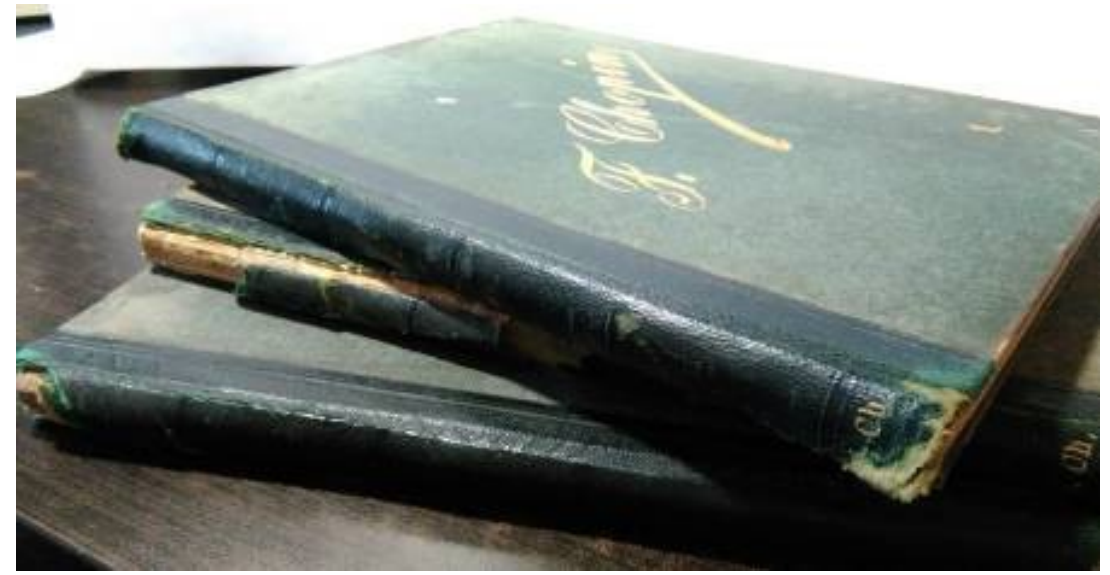

Źródło: BG AMuz: nr inw. N31134-6; sygn.: 78(0.068) Chopi F - Oeuvr 1-3; fot. Marta Walkusz

Pod względem wykorzystanych technik drukarskich, wszystkie druki muzyczne wykonano techniką litograficzna i sztychograficzną (Mazur, 1971, s. 73$)^{12}$, co wiernie oddaje ówczesne tendencje drukarskie kontynuowane od lat 40. XIX wieku ${ }^{13}$ do lat 60. XX wieku głównie ze względu na czystość i wyrazistość zapisu nutowego (Sawicki, 1965, s. 5).

\section{Relacje kontrahenckie między wydawcami a drukarniami}

L Jak już wspomniano, wśród warszawskich wydawców nie ma żadnego, który specjalizowałby się wyłącznie w tematyce muzycznej, nutowej. Publikowanie utworów muzycznych stanowi zwykle część ich działalności wydawniczej, u niektórych wydawców wręcz ma znaczenie marginalne, a wydania nut sa jednostkowe. Zawartość Tab. 1. potwierdza, że najistotniejszy udział w warszawskim rynku muzycznym miało pięć największych wydawnictw, kolejno: Gebethner i Wolff, F. Hösick, M. Arct oraz G. Sennewald i L. Idzikowski.

\footnotetext{
12 Zazwyczaj same nuty są wykonane metodą sztychograficzną, zaś litografii używano do druku ilustracji okładkowych.

${ }^{13}$ Ruchome czcionki sprawdzały się przede wszystkim w muzyce wokalnej wielogłosowej lub w przykładach nutowych zawartych w tekście książki. W przypadku faktury fortepianowej, w której największą trudność sprawiały wielodźwięki oraz rozmaite znaki spoza pięciolinii, takie jak oznaczenia pedalizacji, ozdobników, akolady itp., o wiele prościej było korzystać z techniki litograficznej lub miedziorytniczej. Należy wspomnieć również o tym, że składacz nut musiał mieć przygotowanie muzyczne, a przynajmniej znać poszczególne wartości nut i znaczenie wszelkich muzycznych znaków. Zatrudnienie więc takiego fachowca podnosiło koszty produkcji.
} 
Między Gebethnerem a pozostałymi zakładami zauważalna jest znaczna różnica w ilości wydanych tytułów. W obrębie warszawskich druków muzycznych przechowywanych w BG AMuz brakuje też publikacji wielu zakładów o znaczącym i ugruntowanym wówczas prestiżu, takich jak m.in. Edwarda Wende, firmy Unger \& Banarski czy Michała Glücksberga.

Tab. 1. Rozkład procentowy i ilościowy firm wydawniczych, które opublikowały nuty zawarte w badanej kolekcji

\begin{tabular}{|l|c|c|}
\hline \multicolumn{1}{|c|}{ Nazwa wydawnictwa } & $\begin{array}{c}\text { Liczba } \\
\text { wydanych } \\
\text { tytułów }\end{array}$ & $\begin{array}{c}\text { Procent } \\
\text { udziału }\end{array}$ \\
\hline Gebethner i Wolff & 278 & 74,93 \\
\hline F. Hösick & 22 & 5,93 \\
\hline M. Arct & 16 & 4,31 \\
\hline L. Idzikowski & 12 & 3,23 \\
\hline Echo Muzyczne & 9 & 2,43 \\
\hline G. Sennewald & 9 & 2,43 \\
\hline Echo Muzyczne + Rajchman i Frendler & 3 & 0,81 \\
\hline Julian Müller & 3 & 0,81 \\
\hline B. Rudzki & 2 & 0,54 \\
\hline G. Sennewald + F. Hofmeister & 2 & 0,54 \\
\hline Meloman & 2 & 0,54 \\
\hline Rajchman i Frendler & 2 & 0,54 \\
\hline Warszawskie Towarzystwo Muzyczne & 2 & 0,54 \\
\hline Wydawnictwo Kasy Przezorności i Pomocy & 2 & 0,54 \\
Warszawskich Pomocników Księgarskich & 1 & 0,27 \\
\hline G. Sennewald + L. Idzikowski & 1 & 0,27 \\
\hline G. Sennewald + P. Jurgenson & 1 & 0,27 \\
\hline Jerzy Dunin-Borkowski & 1 & 0,27 \\
\hline Kruziński et Lewi & 1 & 0,27 \\
\hline Maurycy Orgelbrand & 1 & 0,27 \\
\hline nakład własny P. Maszyńskiego & $\mathbf{3 7 1}$ & $\mathbf{1 0 0 , 0 0}$ \\
\hline S. Sadowski & & \\
\hline & SUMA: & \\
\hline
\end{tabular}

Źródło: opracowanie własne 
Spośród czasopism muzycznych jednostkowo pojawiają się nuty będące dodatkiem do „Echa Muzycznego” i „Melomana”. Nie ma natomiast żadnych nut dołączonych do czasopism niemuzycznych.

Jeśli chodzi o zakłady drukarskie, można wskazać takie, które specjalizują się w tłoczeniu nut. Zależności między nakładcami a zakładami poligraficznymi należy rozpatrywać w obie strony, tzn. wykazać, u kogo drukował nuty dany wydawca oraz od kogo przyjmował zlecenia dany zakład drukarski. Najwięksi wydawcy zlecali druk nut nie tylko warszawskim zakładom graficznym. Tylko na podstawie tego niewielkiego wycinka nutowej wytwórczości wydawniczej, jakim jest zbiór przechowywany w BG AMuz, wykazano, że Gebethner i Wolff współpracował z blisko 20 drukarniami, w tym także z działającymi w Lipsku i Moskwie. Pozostali wydawcy zlecali druk nut stałym, maksymalnie trzem, czterem drukarniom. Omawiane relacje kontrahenckie najczytelniej jest ując w układzie tabelarycznym (Tab. 2.). Bardzo istotne w tym przypadku było odróżnienie zakładu zajmującego się wyłącznie tłoczeniem nut od tego zakładu, który wydrukował jedynie np. elementy okładki (a nawet tylko samą ilustrację wytłoczoną np. z kamei) lub reklamy nakładcy. Informacja o tego rodzaju druku pochodziła najczęściej właśnie z ostatniej strony lub ze strony tytułowej. Nuty posiadają więc często dwóch drukarzy. Istnieja jednak przypadki, gdzie drukarz uznany za „nutowego" umieszczony był właśnie w miejscu „okładkowego”. Był jednak jedynym drukarzem wymienionym w druku, uznano więc, że w jego zakładzie wytłoczono wszystkie elementy egzemplarza. Nie ma wątpliwości, że istotnie tak było, jeśli w grę wchodzi tak duża firma jak np. Pospieszna Litografia i Sztycharnia Nut Juliana Mękarskiego, Drukarnia Piotra Laskauera lub Zakłady Graficzne Bolesława Wierzbickiego, jak również drukarnie zagraniczne. W trakcie prac preparacyjnych zastosowano więc następujące rozróżnienie: nuty, gdzie wypunktowano nazwy zakładów spisane z okolic zapisu nutowego; okładka, umieszczając w tej kategorii tych drukarzy, którzy są wymienieni poza nutami, a w szczególności na okładkach, w tym przy ilustracji; całość, gdzie podano jedną drukarnię, niezależnie od miejsca występowania. Zabieg ten pozwolił na wyselekcjonowanie zakładów drukarskich uznanych za specjalizujących się w nutach, tzn. tylko tych drukarni, których nazwy znaleziono w okolicach zapisu nutowego, oraz tych zaliczonych do kategorii „całość” (Tab. 2.): 
Tab. 2. Wykaz drukarni warszawskich specjalizujących się w druku nut wraz z wykazem ich zleceniodawców na przykładzie muzykaliów z lat 1875-1918 przechowywanych w Gdańsku

\begin{tabular}{|c|c|}
\hline Drukarnia & Wydawca \\
\hline $\begin{array}{l}\text { Drukarnia Andrzeja Tadeusza } \\
\text { Jezierskiego }\end{array}$ & Gebethner i Wolff \\
\hline $\begin{array}{l}\text { Drukarnia i Litografia B.A. Bukaty } \\
\text { w Warszawie }\end{array}$ & Gebethner i Wolff \\
\hline $\begin{array}{l}\text { Drukarnia i Litografia Jana Cotty } \\
\text { w Warszawie }\end{array}$ & $\begin{array}{ll}\text { - } & \text { Gebethner i Wolff, } \\
\text { - } & \text { Warszawskie Towarzystwo Muzyczne. }\end{array}$ \\
\hline $\begin{array}{l}\text { Drukarnia Ludwika Bilińskiego } \\
\text { i Wacława Maślankiewicza }\end{array}$ & Gebethner i Wolff \\
\hline Drukarnia Maurycego Lewińskiego & Gustaw Sennewald \\
\hline Drukarnia Piotra Laskauera & Gebethner i Wolff \\
\hline $\begin{array}{l}\text { Drukarnia Rubieszewskiego } \\
\text { i Wrotnowskiego w Warszawie }\end{array}$ & Gebethner i Wolff \\
\hline $\begin{array}{l}\text { Drukarnia Społeczna Stowarzysze- } \\
\text { nia Robotników Chrześcijańskich }\end{array}$ & $\begin{array}{ll}\text { - } & \text { Gebethner i Wolff, } \\
\text { - } & \text { L. Idzikowski. } \\
\end{array}$ \\
\hline Drukarnia Wacława Piekarniaka & Gebethner i Wolff \\
\hline $\begin{array}{l}\text { Litografia Carla Göttlieba Rödera } \\
\text { w Lipsku }\end{array}$ & $\begin{array}{l}\text { - Gebethner i Wolff, } \\
\text { - Gustaw Sennewald. }\end{array}$ \\
\hline Litografia Cypriana Witanowskiego & $\begin{array}{ll}\text { - } & \text { Echo Muzyczne } \\
& \text { (bez udziału Rajchmana i Frendlera), } \\
\text { - } & \text { Ferdynand Hösick, } \\
\text { - } & \text { Gebethner i Wolff, } \\
\text { - } & \text { L. Idzikowski, } \\
\text { - } & \text { Meloman, } \\
- & \text { M. Arct, } \\
\text { - } & \text { Wydawnictwo Kasy Przezorności } \\
& \text { i Pomocy Warszawskich Pomocni- } \\
& \text { ków Księgarskich. } \\
\end{array}$ \\
\hline $\begin{array}{l}\text { Litografia i Sztycharnia Nut } \\
\text { Samuela Orgelbranda Sw } \\
\text { Drukarnia Samuela Orgelbranda } \\
\text { Synów u Gebethnera i Wolffa }\end{array}$ & $\begin{array}{ll}\text { - } & \text { Gebethner i Wolff, } \\
\text { - } & \text { Rajchman i Frendler. }\end{array}$ \\
\hline $\begin{array}{l}\text { Litografia Józef F. Konarzewski } \\
\text { i Julian Mękarski }\end{array}$ & $\begin{array}{l}\text { - } \quad \text { B. Rudzki, } \\
\text { - Gebethner i Wolff. }\end{array}$ \\
\hline Litografia J. Konarzewskiego & $\begin{array}{l}\text { - Gebethner i Wolff, } \\
\text { - S. Sadowski. }\end{array}$ \\
\hline Litografia J. Müllera & Julian Müller \\
\hline
\end{tabular}


Tab. 2. c.d.

\begin{tabular}{|l|l|}
\hline \multicolumn{1}{|c|}{ Drukarnia } & \multicolumn{1}{|c|}{ Wydawca } \\
\hline Litografia J. Mękarskiego & - F. Hösick, \\
& - Gebethner i Wolff, \\
Pośpieszna Litografia i Sztycharnia & - G. Sennewald, \\
Nut J. Mękarskiego u Gebethnera & - Kruziński et Lewi, \\
i Wolffa & - M. Orgelbrand, \\
& - M. Arct, \\
Litografia i Sztycharnia Nut & - Rajchman i Frendler. \\
J. Mękarskiego u F. Hösicka & \\
\hline Sztycharnia K. Drzewiecki & - F. Hösick, \\
& - Gebethner i Wolff, \\
& - L. Idzikowski. \\
\hline Zakład Drukarski Gebethnera & Gebethner i Wolff \\
i Wolffa & \\
\hline Zakłady Graficzne B. Wierzbicki & - F. Hösick, \\
i Sp. w Warszawie & - Gebethner i Wolff. \\
\hline
\end{tabular}

Źródło: opracowanie własne

\section{Podsumowanie}

Z Zbiór varsavianów przechowywanych w BG AMuz, pod względem treściowym wpisuje się w tendencje wydawnicze warszawskich wydawców muzycznych przełomu XIX i XX wieku. Utwory muzyczne skomponowane sa w większości przez najpopularniejszych wówczas polskich i europejskich kompozytorów przełomu XIX i XX wieku, wykorzystują również najbardziej nośne obsady muzyczne, takie jak głos i fortepian oraz fortepian solo. Swoista cechą jest publikowanie dzieł muzycznych w seriach wydawniczych sugerujacych formę muzyczną dzieł oraz ich przeznaczenie wykonawcze.

Biorąc pod uwagę wyniki badań nad typologią warszawskich muzykaliów opublikowanych do 1865 r., badany wycinek repertuaru wydawniczego z lat 1875-1918 stanowi kontynuację rozwiązań w kwestii typograficznej. Pod względem wykorzystanych technik typograficznych zbiór reprezentuje specyfikę warszawskich wydawnictw muzycznych, wykorzystujących w zapisie nutowym głównie technikę sztychograficzna, zaś w zakresie elementów graficznych litografię, a unikających wykorzystywanej w niemieckiej literaturze muzycznej metody ruchomej czcionki.

Dodatkowo, na bazie tego materiału po raz pierwszy scharakteryzowano relacje kontrahenckie między warszawskimi wydawcami a zakładami drukarskimi w okresie 1875-1918 i wytypowano drukarzy sensu stricto muzycznych. 


\section{Charakterystyka muzycznych varsavianów...}

\section{Bibliografia}

\section{Źródła}

Arditi, Luigi ([189?]). L'estasi: Valse na mezzosopran z towarzyszeniem fortepianu, sł. pol. F. Schobera. Warszawa: G. Sennewald (C.G. Röder, Leipzig).

Beethoven, Ludvig van (cenz. 1899 [druk po 1903]). Drobnostka = Bagatelle op. $33 \mathrm{nr} 1$ [na fortepian]. Varsovie: chez F. Hösick (w lit. C. Witanowskiego Krakowskie Przedmieście 2).

Bellini, Vincenzo ([około 1865]). Norma: Arya Orovesa. Warszawa: nakładem G. Sennewalda (Sztych i druk C.G. Rödera w Lipsku).

Bettinelli, Angelo ([1911]). Tesknota = Lontananza [na głos i fortepian], sł. pol. T. Leliwy. Warszawa: Gebethner i Wolff.

Brahms, Johannes ([19?]). Danse hongroise No. 4 pour violon avec accompagnement de piano, revues et doigtées par Romuald Aust. Varsovie: Gebethner \& Wolff.

Chopin, Fryderyk ([1877]). Oeuvres pour le Piano, vol. 1-3. Varsovie: Gebethner et Wolff.

Chopin, Fryderyk ([1905-1910]). Wojak op. 74 no. 10 [na głos i fortepian]. Warszawa: Gebethner i Wolff.

Chopin, Fryderyk ([1909-1913]). Mazourka op. 7 no. 1 pour Piano, Violon et Cello, arr. par Prof. A. Cink. Varsovie: Gebethner \& Wolff (Druk. i Lit. Jana Cotty w Warszawie, ul. Kapucyńska 7).

Dargomyżski, Aleksandr ([po 1911]). Nocowała chmurka złotowtosa = Nocevala tucka zolotaja, trio [na sopran, tenor, baryton i fortepian], tekst ros. M. Lermontowa. Warszawa: Leon Idzikowski (w Drukarni Społecznej Stowarzyszenia Robotników Chrześcijańskich, Pl. Grzybowski 3/5; [nuty:] Sztych. K. Drzewiecki).

Denza, Luigi ([19?]a). Cudne oczy = Occhi turchini [na głos i fortepian], sł. pol. W. Rapackiego (syna). Warszawa: B. Rudzki.

Denza, Luigi ([19?]b). O! Gdyby's mnie kochała! = Si tu m'aimais!, przekł. M. Radziszewskiego. Warszawa: Hösick.

Estreicher, Karol (1876-). Bibliografia polska XIX. stólecia. Kraków: Uniwersytet Jagielloński. Gabussi, Vincenzo [19?], Rybacy = I pescatori, duetto per tenore e basso. Varsovie: F. Hösick.

Grieg, Edvard H. ([około 1910]). Śmierć Azy = (La mort d'Ase) op. 46 no. 2. Warszawa: B. Rudzki (W-wa, Nowy Świat 47, Lit. J.F. Konarzewski i I. Mękarski).

Grieg, Edvard H. ([po 1912?). Ja kocham cie = Je t'aime [na głos i fortepian], tłom.: M. Radziszewski. Warszawa: Gebethner i Wolff (Zakłady Graficzne Wierzbicki i S-ka).

Hasta "Lutni" oraz stowarzyszen spiewackich w Warszawie, w Lodzi, w Kaliszu, w Radomiu, w Wieluniu [na chór męski a cappella] ([1898]). Warszawa: Echo Muzyczne.

Heiser, Wilhelm ([1890-1915]). Na grobie op. 30 [na głos i fortepian], sł. pol. W. Rapackiego, syna. Warszawa: Michał Arct. Pobrano 17 października 2018, z: http://pbc.gda.pl/dlibra/docmetadata?id=32842

Kossobudzki, Ignacy ([1908-1912]). Stach = Mädchensklage, [pieśń] na głos [wysoki] z towarzyszeniem fortepianu, sł. Or-Ot'a; Deutsch von G. Guranowski. Warszawa: Gebethner i Wolff.

Kücken, Friedrich W. (cenz. 1882). Serenada Maurytańska, sł. pol. R. Nowiny. Warszawa: nakładem G. Sennewalda (w Lit. Mękarskiego, Krakowskie Przedmieście 38 w Warszawie).

Liszt, Franz ([przed 1900]). Rapsodie Hongroise no. 2, s. 244, pour piano. Varsovie: chez Ferdinand Hösick (Litografia i Sztycharnia Nut J. Mękarskiego No. 411 Krak. Przedm). 


\section{Marta Walkusz}

Makowski, Henryk \& Surzyński, Mieczysław ([po 1895]). S Zkoła na organy, cz. 1. Warszawa: nakład i własność Gebethnera i Wolffa (Lit. J. Konarzewski).

Marks, G.W. ([po 1911]). Potpourri sur des motifs de l'Opéra „Der Freischütz” de Weber, pour le piano. Varsovie: Léon Idzikowski (Impr. de Musique J. Tchokoloff, Kieff).

Massenet, Jules ([około 1895]). Noc w Hiszpanii = Nuit d'Espagne, tłom. M. Radziszewski. Warszawa: F. Hösick.

Mendelssohn-Bartholdy, Feliks ([189?]). Na okrecie = Wasserfahrt [na dwa głosy z fortepianem], sł. H. Heine; sł. pol. J. Chęcińskiego. Warszawa, F. Hösick.

Moniuszko, Stanisław ([1909]). Milda, kantata mitologiczna litewska partytura orkiestrowa sprawdzona i do druku przyg. przez P. Maszyńskiego, sł.: J. I. Kraszewski. Warszawa: Warszawskie Towarzystwo Muzyczne, Sekcja im. S. Moniuszki; sgł. Gebethner i Wolff.

Moniuszko, Stanisław ([po 1908]). Halka, ouverture pour Piano a deux mains. Warszawa: Gebethner \& Wolff.

Moniuszko, Stanisław (cenz. 11.06.1901). Dla czego [na baryton z towarzyszeniem fortepianu], sł.: autor nieznany. Warszawa: Gebethner i Wolff (Litogr.: J. Mękarski).

Moszkowski, Maurycy (cenz. 1883). Oczęta = Mädchenang, sł. pol. M. Radziszewskiego. Varsovie: chez Kruziński et Lewi (w Lit. Mękarskiego 38 Krak. Przedm. w Warszawie).

Münchheimer, Adam ([po 1908]). Graduale ze Mszy Solennej, na Bas lub Baryton z towarzyszeniem organu lub fortepianu. Warszawa: Gebethner i Wolff (Druk. W. Piekarniaka).

Ohrt, Janina (oprac.) (1969). Towarzystwo imienia Fryderyka Chopina: katalog zbiorów, nuty. Warszawa: Towarzystwo im. Fryderyka Chopina.

Pankiewicz, Eugeniusz ([1912-1915]). Sześć pieśni weselnych ludowych polskich, w formie suity na dwa głosy żeńskie (albo chór żeński) i fortepian na cztery ręce. Warszawa: Gebethner i Wolff.

Przeglad Bibliograficzny Ksiegarni Gebethnera i Wolffa w Warszawie, wrzesień $1913 \mathrm{nr} 9$. Pobrane 17 października 2018, z: http://bc.wbp.lublin.pl/dlibra/plain-content? id=14096.

Schubert, Franz ([około 1890]). Zdrowaś Marya = Modlitwa matki D:839 na głos wysoki z tow. fortepianu, przeł. z niem. J. Chęciński; sł. franc. P. Bélanger. Warszawa: F. Hösick.

Schubert, Franz (cenz. 1899). Ostatnia nadzieja = Letzte Hoffnung, sł. pol. naśladował z poezji Hajoty W. Aleksandrowicz. Warszawa: Wydawnictwo Stanisława Sadowskiego (Lit. Konarzewskiego Nowy Świat 38 w Warszawie).

Singer, Zygmunt ([około 1912]). Méthode pour Hautbois Théorique et Pratique:... l'usage des joueurs avancés pour le développement artistique en VI parties, [1], op. 12. Varsovie: Gebethner \& Wolff; Berlin: Albert Stahl.

Starczewski, Feliks (1916). Bija sie dwaj Cyganie, śpiew z towarzyszeniem fortepianu. Warszawa; Kraków: nakład i własność wydawców Gebethner i Wolff (Lit. J.F. Konarzewski i J. Mękarski, Nowy Świat 47 w Warszawie).

Suppé, Franz von (cenz. 1915). Poëte et Paysan, ouverture pour piano. Varsovie: Gebethner \& Wolff (Druk L. Bilińskiego i W. Maślankiewicza, Warszawa, Nowogrodzka 17).

Troschel, Wilhelm ([około 1880]). Mój kwiatek, wiersz M.B. Antoniewicza. Warszawa: G. Sennewald (Lipsk: sztych i druk C.G. Rödera).

Troschel, Wilhelm ([po 1910?]). Mój kwiatek, romans [na głos i fortepian], wiersz M.B. Antoniewicza. Warszawa: Gebethner i Wolff (Druk. i Lit. Jana Cotty w Warszawie).

Troschel, Wilhelm (cenz. 1887). Czarodziejka, śpiew, sł. Deotymy. Warszawa: nakład G. Sennewalda (lit. Mękarskiego 40 Krak. Przedm. w Warszawie).

Verdi, Giuseppe ([około 1910]). Traviata: Violetta [na mezzosopran lub baryton i fortepian]. Warszawa: nakład i własność wydawców Gebethner i Wolff. 


\section{Charakterystyka muzycznych varsavianów...}

Wieniawski, Henryk ([po 1913]). Modlitwa do Najswietszej Maryi Panny Ostrobramskiej op. 16 [na głos wysoki z towarzyszeniem organu lub fortepianu], sł. Domher. Warszawa: Gebethner \& Wolff (Lit. C. Witanowski, Oboźna 9).

Wroński, Adam (cenz. 1899). Tęsknota, piosenka z tow. fortepianu op. 149, sł. N. N. Warszawa: Gebethner \& Wolff (Lit. Mękarski, Krakowskie Przedmieście 40 w Warszawie).

Żeleński, Władysław (cenz. 1900). Łaskawa dziewczyna op. $25 \mathrm{nr} 5$ [na głos i fortepian]. Warszawa: F. Hösick.

\section{Literatura}

Arct, Stanisław \& Pawłowska, Elżbieta (1961). Wydawcy warszawscy w latach 1878-1914. W: S. Tazbir (red.) $Z$ driejów ksiażki $i$ bibliotek w Warsqawie (s. 320-384). Warszawa: Państwowy Instytut Wydawniczy.

Bibliografia Polska 1901-1939 (1986-). Warszawa: Biblioteka Narodowa.

Bułhak, Henryk (1977). Metoda typograficzna w badaniach nad dawną książką. Uwagi i refleksje, Biuletyn Poligraficzny, 2, 37-52.

Chomiński, Józef M. \& Turło, Teresa D. (1990). Katalog dzieł Fryderyka Chopina. Kraków: Polskie Wydawnictwo Muzyczne.

Mazur, Krzysztof (1970). Pierwodruki Stanisława Moniuszki. Warszawa: Państwowe Wydawnictwo Naukowe.

Mazur, Krzysztof (1971). Polskie edytorstwo muzyczne między powstaniem listopadowym a styczniowym. W: Z. Chechlińska (red.), Szkice o kulturze muzycznej XIX w., Studia $i$ materialy z XIX w., t. 1 (s. 51-89). Warszawa: Państwowe Wydawnictwo Naukowe.

Poniatowska, Irena (2000). Moszkowski Moritz. W: E. Dziębowska (red.), Encyklopedia Muzyczna PWM, czesść biograficzna [T. 6] (s. 384-385). Kraków: Polskie Wydawnictwo Muzyczne.

Prosnak, Antoni (1993). Chopinowskie cimelia nutowe w Bibliotece AMFC. Warszawa: Akademia Muzyczna im. Fryderyka Chopina.

Prosnak, Antoni (1997). Dawne nuty drukowane w cimeliach AMFC. Warszawa: Akademia Muzyczna im. Fryderyka Chopina.

Prosnak, Antoni (2003). Cimelia AMFC po 1850. Warszawa: Akademia Muzyczna im. Fryderyka Chopina.

Sawicki, M. (1965). Matryce nutowe. Wiadomości Graficzne. Czasopismo Zwiazku Zawodowego Pracowników Poligrafii, R. 45, 6, 5.

Spózowie, Andrzej \& Irena (2000). Katalog polskich druków muzycznych 1801-1875 w zbiorach Biblioteki, Muzeum i Archiwum Warszawskiego Towaraystwa Mugycznego im. Stanistawa Moniuszki. Warszawa: Warszawskie Towarzystwo Muzyczne im. Stanisława Moniuszki.

Tomaszewski, Wojciech (1992a). Bibliografia warsqawskich druków muaycznych 1801-1850, Warszawa: Biblioteka Narodowa.

Tomaszewski, Wojciech (1992b). Warszawskie edytorstwo mugyczne w latach 1772-1865, Warszawa: Biblioteka Narodowa. 
Characteristics of Varsavianas published in the years 1875-1918 stored in the Main Library of the Stanisław Moniuszko Music Academy in Gdańsk

ABSTRACT: The Warsaw musical editing from the last quarter of the nineteenth century is a material that has not been touched up in bibliological and musicological researches. Basing on the methodology used in the publication of Warsaw musical editing in the years 1772-1865 by Wojciech Tomaszewski (Warsaw 1992b), the author of article has made a similar characterization of printed music issued with the Warsaw publishing address in the years 1875-1918, stored in the Main Library of the Stanisław Moniuszko Music Academy in Gdańsk [abbr.: BG AMuz]. She also has paid attention to a topic not examined so far - the relations between publishers and printers appearing in the varsavianas preserved in BG AMuz and she has isolated musical printers sensu stricto.

KEYWORDS: Warsaw printed music; Warsaw music publishers; book collections; musical typography; Main Library of the Stanisław Moniuszko Music Academy in Gdańsk 